Original article / Оригинальная статья

DOI: http://dx.doi.org/10.21285/1814-3520-2021-4-463-477

\title{
Service life tests for storage batteries used in islanded power systems with renewable energy sources
}

\author{
Sergey G. Obukhov*, Igor A. Plotnikov*, Vladimir G. Masolov** \\ ${ }^{*}$ Tomsk Polytechnic University, Tomsk, Russia \\ ${ }^{*}$ VDM-tekhnika LLC, Moscow, Russia
}

\begin{abstract}
We investigated the service life of storage batteries to provide recommendations on the design of energy storage systems used in islanded energy systems based on renewable power sources. The service life of maintenance-free, sealed lead-acid batteries produced by absorbed glass mat (AGM) technology was determined by endurance tests carried out by repeated charge/discharge cycles according to specified load profiles, implemented at a specialized Chroma Test System station. Three battery load profiles were simulated: one for the standard DC charge/discharge mode, and two for the charge/discharge modes from renewable energy sources. To this end, the actual data obtained from monitoring the operating modes of a wind power plant were used. It was found that the battery service life depends on the intensity of stress factors. Among them, the throughput factor has the most pronounced influence on the battery lifespan. To extend the service life of storage batteries, it is proposed to separate the charge/discharge modes in time. For batteries operated on renewable energy profiles, this approach decreases time intervals between full charges and at low battery levels, which increases the battery service life by $14 \%$. A solution to designing an energy storage system for microgrids was proposed, which consists in the use of a combined double-circuit energy storage unit. An experimental prototype of such a unit with a power of $15 \mathrm{~kW}$ was developed. The use of a combined energy storage unit in the microgrid system: increases the battery service life by $20-30 \%$ compared to analogues; improves the static and dynamic stability of the local energy system with a response time of no more than $50 \mathrm{~ms}$ towards power change; allows a fuel replacement level of at least $25 \%$; reduces the electricity cost by $25-30 \%$.
\end{abstract}

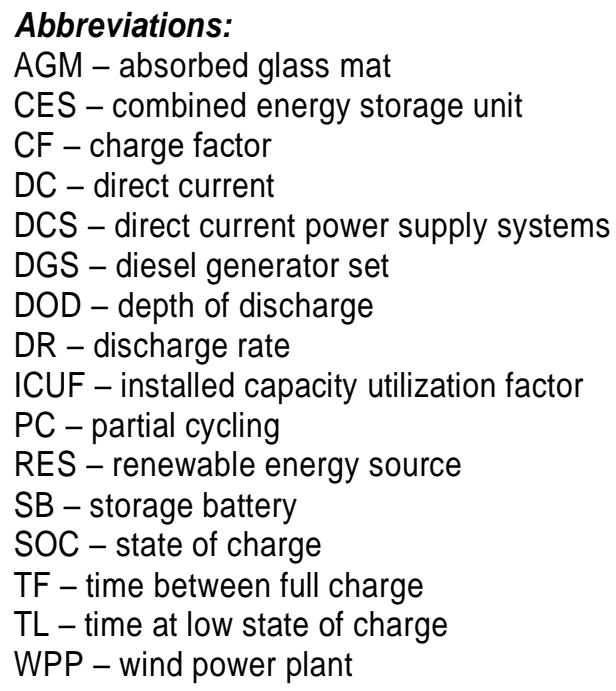

Keywords: isolated energy system, renewable energy sources, energy storage, rechargeable battery

For citation: Obukhov SG, Plotnikov IA, Masolov VG. Service life tests for storage batteries used in islanded power systems with renewable energy sources. Vestnik Irkutskogo gosudarstvennogo tehnicheskogo universiteta = Proceedings of Irkutsk State Technical University. 2021;25(4):463-477. https://doi.org/10.21285/1814-3520-2021-4-463-477 


\title{
Исследование эксплуатационного ресурса аккумуляторных батарей в изолированных энергетических системах с возобновляемыми источниками энергии
}

\author{
(С) С.Г. Обухов*, И.А. Плотников*, В.Г. Масолов** \\ *Национальный исследовательский Томский политехнический университет, г. Томск, Россия \\ ${ }^{*}$ ООО «ВДМ-техника», г. Москва, Россия
}

\begin{abstract}
Резюме: Цель - исследование эксплуатационного ресурса аккумуляторных батарей и разработка рекомендаций по построению систем накопления энергии для изолированных энергетических систем с возобновляемыми источниками энергии. Объектом исследований явились необслуживаемые, герметичные свинцово-кислотные батареи, выполненные по AGM-технологии. Срок службы аккумуляторных батарей определялся по результатам их ресурсных испытаний посредством заряда/разряда по заданным профилям нагрузки, реализованных на специализированной испытательной станции Chroma Test System. Для проведения экспериментов были смоделированы 3 профиля нагрузки батарей: один - для стандартного режима заряда/разряда на постоянном токе, и два для режимов заряда/разряда от возобновляемых источников энергии, для формирования которых использовались фактические данные мониторинга рабочих режимов ветроэнергетической установки. Результаты экспериментов показали, что условия эксплуатации батарей по рассматриваемым профилям существенно различаются по значениям практически всех стресс-факторов, из которых определяющее влияние на срок службы батарей оказывает фактор пропускной способности. Для сохранения эксплуатационного ресурса аккумуляторных батарей предложено разделение во времени их режимов заряда/разряда. Результаты испытаний показали, что при эксплуатации батарей по профилям от возобновляемых источников энергии применение данного способа сокращает временные интервалы между полной зарядкой и при низком уровне заряда батарей, что обеспечивает повышение их срока службы до 14\%. Предложено новое техническое решение по построению системы накопления энергии для MicroGrid в виде комбинированного двухконтурного накопителя энергии. Изготовлен экспериментальный образец комбинированного накопителя энергии на мощность 15 кВт. Применение комбинированного накопителя энергии в составе MicroGrid позволяет повысить эксплуатационный ресурс аккумуляторных батарей до 20-30\% в сравнении с аналогами, обеспечивает статическую и динамическую устойчивость локальной энергетической системы со временем реакции на изменение мощности не более 50 мс, уровень замещения топлива не менее $25 \%$ и снижение стоимости электроэнергии на 25-30\%.
\end{abstract}

\section{Аббревиатуры:}

AGM - герметичные свинцово-кислотные батареи, выполненные по AGM-технологии

КНЭ - комбинированный накопитель энергии

CF - фактор заряда

$\mathrm{DC}$ - постоянный ток

СЭП - система электропитания на постоянном токе

ДГУ - дизель-генераторная установка

DOD - максимальная глубина разряда

$\mathrm{DR}$ - скорость разряда

КИУМ - коэффициент использования установленной мощности

ПК - частичный цикл

ВИЭ - возобновляемый источник энергии

АБ - аккумуляторная батарея

$\mathrm{SOC}$ - контроль остаточной емкости

TF - время работы между полной зарядкой

$\mathrm{TL}$ - время работы при низком уровне заряда

ВЭС - ветроэлектростанция

Ключевые слова: изолированная энергетическая система, возобновляемые источники энергии, накопитель энергии, аккумуляторная батарея

Для цитирования: Обухов С.Г., Плотников И.А., Масолов В.Г. Исследование эксплуатационного ресурса аккумуляторных батарей в изолированных энергетических системах с возобновляемыми источниками энергии. Вестник Иркутского государственного технического университета. 2021. Т. 25. № 4. С. 463-477. https://doi.org/10.21285/1814-3520-2021-4-463-477 


\section{INTRODUCTION}

Islanded energy systems based on various generating units, such as microgrids ${ }^{1}$, are promising technologies for producing electrical energy. Microgrid technology was initially aimed at increasing the energy efficiency and environmental friendliness of autonomous power supply systems that incorporate diesel generator sets (DGS). Therefore, the developers relied on the use of renewable energy sources (RES), both wind power plants (WWP) and photovoltaic installations.

Microgrids can operate either in gridconnected or islanded mode. According to the Navigant Research analytical company, in 2018, the annual production of islanded and gridconnected microgrids amounted to 1,231 MW and 1,463 MW, respectively, with the total sales volume exceeding USD 3 billion. By 2027, the market demand for such microgrids is predicted to reach 4,230 MW and 11,576 MW, respectively, which will require investments of about USD 30 billion? ${ }^{2}$.

Microgrid equipment has a large potential in Russia, whose eastern and northern areas are characterized by a low population density and a poorly-developed transport infrastructure. Relia- ble power supply in decentralized regions is an urgent state task, confirmed by a number of legal and regulatory documents ${ }^{3,4}$.

Microgrids incorporate energy storage systems, which significantly improve energy efficiency by increasing the installed capacity utilization factor of renewable energy installations, reducing the DGS operating hours, and, accordingly, decreasing fuel and service costs ${ }^{5}$.

Storage batteries (SB) as energy storage systems satisfy the requirements of microgrids in terms of power range and energy storage duration. Despite significant progress in the industry of electrochemical power sources [2, 3], leadacid SBs are mainly used for storing energy in microgrids due to their good value-for-money characteristics. In this work, we also consider this type of SBs.

The expenses involved with energy storage are quite significant, amounting from 25 to $60 \%$ of the total cost of an energy system [4, 5]. Therefore, it is important to increase the SB service life, which is typically lower than that of other microgrid components [6]. To that end, the main factors affecting the lifespan of SBs when used in microgrids should be identified. It should be noted that the operating modes of SBs incor-

\footnotetext{
${ }^{1}$ Off-grid renewable energy solutions to expand electricity access: an opportunity not to be missed. International Renewable Energy Agency. Available from: https://www.irena.org/publications/2019/Jan/Off-grid-renewable-energysolutions-to-expand-electricity-to-access-An-opportunity-not-to-be-missed [Accessed 17th February 2021] / Off-grid renewable energy solutions to expand electricity access: an opportunity not to be missed // International Renewable Energy Agency [Электронный ресурc]. URL: https://www.irena.org/publications/2019/Jan/Off-grid-renewable-energysolutions-to-expand-electricity-to-access-An-opportunity-not-to-be-missed (17.02.2021).

${ }^{2}$ What's Driving Microgrids toward a \$30.9B Market. Microgrid Knowledge. Available from:

https://microgridknowledge.com/microgrid-market-navigant/ [Accessed 17th February 2021] / What's Driving Microgrids toward a \$30.9B Market // Microgrid Knowledge [Электронный ресурc]. URL:

https://microgridknowledge.com/microgrid-market-navigant/ (17.02.2021).

${ }^{3}$ Decree "On national goals and strategic objectives of the development of the Russian Federation for the period up to 2024". President of Russia. Available from: http://www.kremlin.ru/events/president/news/57425 [Accessed 17th February 2021] (In Russ.) / Указ «О национальных целях и стратегических задачах развития Российской Федерации на период до 2024 года» // Президент России [Электронный ресурc]. URL:

http://www.kremlin.ru/events/president/news/57425 (17.02.2021).

${ }^{4}$ About the draft plan for the modernization of inefficient diesel, fuel oil and coal generation in hard-to-reach regions. The Government of Russia. Available from: http://government.ru/orders/selection/401/35150/ [Accessed 17th February 2021] (In Russ.) / O проекте плана по модернизации неэффективной дизельной, мазутной и угольной генерации в труднодоступных регионах // Правительство России [Электронный ресурc]. URL:

http://government.ru/orders/selection/401/35150/ (17.02.2021).

${ }^{5}$ Kempener R, Borden E. Battery storage for renewables: market status and technology outlook. International Renewable Energy Agency. Available from: https://cleanenergysolutions.org/resources/battery-storage-renewables-marketstatus-technology-outlook [Accessed 20th February 2021] / Kempener R., Borden E. Battery storage for renewables: market status and technology outlook. International Renewable Energy Agency [Электронный ресурc]. URL: https://cleanenergysolutions.org/resources/battery-storage-renewables-market-status-technology-outlook (20.02.2021).
} 
porated in microgrids differ significantly from those in direct current (DC) power supply systems (DCS).

The concept of charge/discharge cycles and methods for determining the SB service life are defined in regulatory documents ${ }^{6,7}$. In accordance with these requirements ${ }^{6,7}$, each cycle consists of sequential DC charge/discharge steps, and the SB lifetime is determined by a number of cycles, following which the SB capacity is reduced to $80 \%$ compared to the nominal value. When SBs are applied as part of DCSs, the charge/discharge currents vary across the ranges and profiles recommended by the SB producers, ensuring their maximal service life. In such systems, the main factors affecting the SB service life are temperature and the depth of discharge. These dependencies are given in the SB technical specification, allowing determination of their service life when used in a DCS.

A characteristic feature of microgrids is a change in the generated and consumed power values over a wide range, which determines the presence of ripples in the SB charge/discharge currents. Operation of SBs in the impulse current mode leads to a rapid degradation of their performance and a reduction in their service life [7]. The stochastic nature of generation leads to incomplete SB charge/discharge cycles with significant time intervals between full charges and at low residual charge rates, which also diminishes the SB lifetime [8, 9].

The main reasons for SB deterioration are physicochemical processes leading to electrolyte separation, water loss, electrode sulfur poisoning and corrosion, as well as loss of active mass. The intensity of these processes, or the deterioration rate, depends on both SB type and its operating conditions. SB deterioration mechanisms are described in $[10,11]$. The main factors affecting these processes are defined in
$[12,13]$. A qualitative estimation of the effect of these factors on SB degradation is given in $[13,14]$. The aforementioned studies determined the main stress factors during SB operation, considerably accelerating degradation processes:

- temperature;

- charge factor (CF);

- throughput $\left(Q_{\text {thr }}\right)$;

- discharge rate (DR);

- time between full charge (TF);

- time at low state of charge (TL);

- partial cycling (PC).

Determination of reliable quantitative relationships between stress factors, degradation mechanisms and the SB lifespan is a challenging research problem attracting widespread interest [15-26]. The high complexity of this problem is associated with the stochastic nature and mutual influence of stress factors affecting SB deterioration processes.

Mathematical modelling is the primary and, in many cases, sole way to predict the service life of SBs incorporated in microgrids. The majority of studies apply the following 3 types of models: performance or charge, voltage and lifetime. Performance models, where the SB service life is determined by the state of charge $[15,16]$, are used most widely. Voltage models measure the voltage at the SB cleats, on the basis of which losses and the degradation degree are calculated [17]. Service life models rely on empirical relationships linking stress factors with the SB service life [18, 19]. All these models can be used independently or integrated into a generalized SB model $[20,21]$. A comparison of various models is presented in [22, 23]; the questions of practical application of SB models when selecting an optimal composition of microgrid equipment are considered in [16, 24, 25].

\footnotetext{
${ }^{6}$ GOST R MEK 60896-21-2013. Stationary lead-acid batteries. Part 21. Controlled valve type. Test methods. Introduced on 1st January, 2015. Moscow: Standartinform, 2015./ГОСТ Р МЭК 60896-21-2013. Батареи свинцово-кислотные стационарные. Часть 21. Типы с регулирующим клапаном. Методы испытаний.Введ.01.01.2015.М.: Стандартинформ, 2015.

${ }^{7}$ GOST R MEK 61427-1-2014. Accumulators and storage batteries for renewable energy sources. General requirements and test methods. Part 1. Application in stand alone photovoltaic power systems. Introduced on 1st January, 2016. Moscow: Standartinform, 2016/ГОСТ Р МЭК 61427-1-2014. Аккумуляторы и аккумуляторные батареи для возобновляемых источников энергии. Общие требования и методы испытаний. Часть 1. Применение в автономных фотоэлектрических энергетических системах. Введ. 01.01.2016. М.: Стандартинформ, 2016.
} 
The studies discussed above aimed to develop SB deterioration models that reliably and accurately describe the effect of stress factors on the SB lifespan. However, a serious limitation to the practical implementation of RES-based microgrids is a lack of approaches to extending the SB service life and creating efficient energy storage systems.

In this work, we investigate the service life of SBs operated in microgrids to propose recommendations on the design of energy storage systems for use in islanded RES energy systems.

\section{MATERIALS AND METHODS}

Maintenance-free, sealed lead-acid batteries produced by AGM technology, CS3 battery trademark, GP 12120 model $^{8}$ were investigated. The main technical characteristics of CSB GP 12120 SB are given in tab. 1.

Table 1. CSB GP 12120 SB nominal characteristics Таблица 1. Паспортные характеристики АБ CSB GP 12120

\begin{tabular}{|l|c|}
\hline \multicolumn{1}{|c|}{ Characteristic } & Value \\
\hline Rated voltage & $12 \mathrm{~V}(6$ cells per battery $)$ \\
\hline Rated capacity & $\begin{array}{r}12 \mathrm{~A} \cdot \mathrm{h} \text {, at a discharge } \\
\text { of } 0.05 \mathrm{C} \text { to } 1.75 \mathrm{~V} \text { per cell }\end{array}$ \\
\hline Voltage under load & $13.5-13.8 \mathrm{~V}$ \\
\hline Charge voltage & $14.4-15 \mathrm{~V}$ \\
\hline $\begin{array}{l}\text { Maximum discharge } \\
\text { current }\end{array}$ & $150 / 180 \mathrm{~A}$ for $5 \mathrm{~s}$ \\
\hline Short circuit current & $378 \mathrm{~A}$ \\
\hline $\begin{array}{l}\text { Maximum charge } \\
\text { current }\end{array}$ & $3.6 \mathrm{~A}$ \\
\hline Internal resistance & $16 \mathrm{~m} \Omega$ \\
\hline Resource & Up to 260 cycles at $100 \%$ discharge \\
\hline Lifetime when idle & Up to 5 years standby time at $25^{\circ} \mathrm{C}$ \\
\hline
\end{tabular}

Due to the high complexity involved with the mathematical description of electrochemical and thermal processes in SBs, direct experiment was chosen as the research method producing valid results.
The batteries were tested using a Chroma 17011 Test System (7208M-6-30 model). This system is used for testing battery cycle life by repeated charging/discharging according to the specified load profiles, allowing estimation of the battery capacity and internal resistance with an error of up to $0.02 \%{ }^{9}$.

SB life tests were carried out according to the requirements for test methods established in regulatory documents ${ }^{6,7}$. During the experiments, the SB degradation rate was determined at various charge/discharge profiles. Three SB load profiles were simulated: one for the standard DC charge/discharge mode, and two for the charge/discharge modes when using a RES. The maximum values of the charge and discharge current for all profiles were limited to 3.6 A and 2.4 A, respectively, which correspond to a 3-hour discharge current according to the battery passport. The maximum depth of discharge (DOD) was taken equal to $80 \%$. The state of charge (SOC) and gas release values were continuously monitored during the experiments. The tests were carried out at a temperature of $24{ }^{\circ} \mathrm{C}$ and an air humidity of $60-70 \%$.

The selected parameters of charge/discharge profiles correspond to severe SB operating modes, leading to the fastest possible degradation of their operating characteristics. Therefore, in all the experiments, we applied a used SB, in which 3 cells of a similar residual capacity were selected according to the results of preliminary tests.

The profile of RES1 was formed using the actual data obtained by monitoring the operating modes of a WPP VDM-2kW wind turbine produced by VDM-tekhnika LLC, installed at a wind farm in Dubna ${ }^{10}$. The WPP output power log data recorded at 1 second intervals were normalized to the required experimental conditions. The change in the SB charge/discharge current, corresponding to the RES1 profile, is shown in

\footnotetext{
${ }^{8}$ Official site of the CSB Energy Technology Co., Ltd. Available from: https://www.csb-battery.com/ [Accessed 21st February 2021]/Официальный сайт компании CSB Energy Technology Co., Ltd. [Электронный ресурc]. URL: https://www.csb-battery.com/ (21.02.2021).

${ }^{9}$ Official site of the ZTS, Inc. Available from: https://www.ztsinc.com/ [Accessed 21st February 2021] / Официальный сайт компании ZTS, Inc. [Электронный ресурc]. URL: https://www.ztsinc.com/ (21.02.2021).

${ }^{10}$ Official site of VDM-technika LLC. Available from: http://www.vdmtech.ru/ [Accessed 21st February 2021] / Официальный сайт компании «ВДМ - техника» [Электронный ресуpc]. URL: http://www.vdmtech.ru/ (21.02.2021).
} 


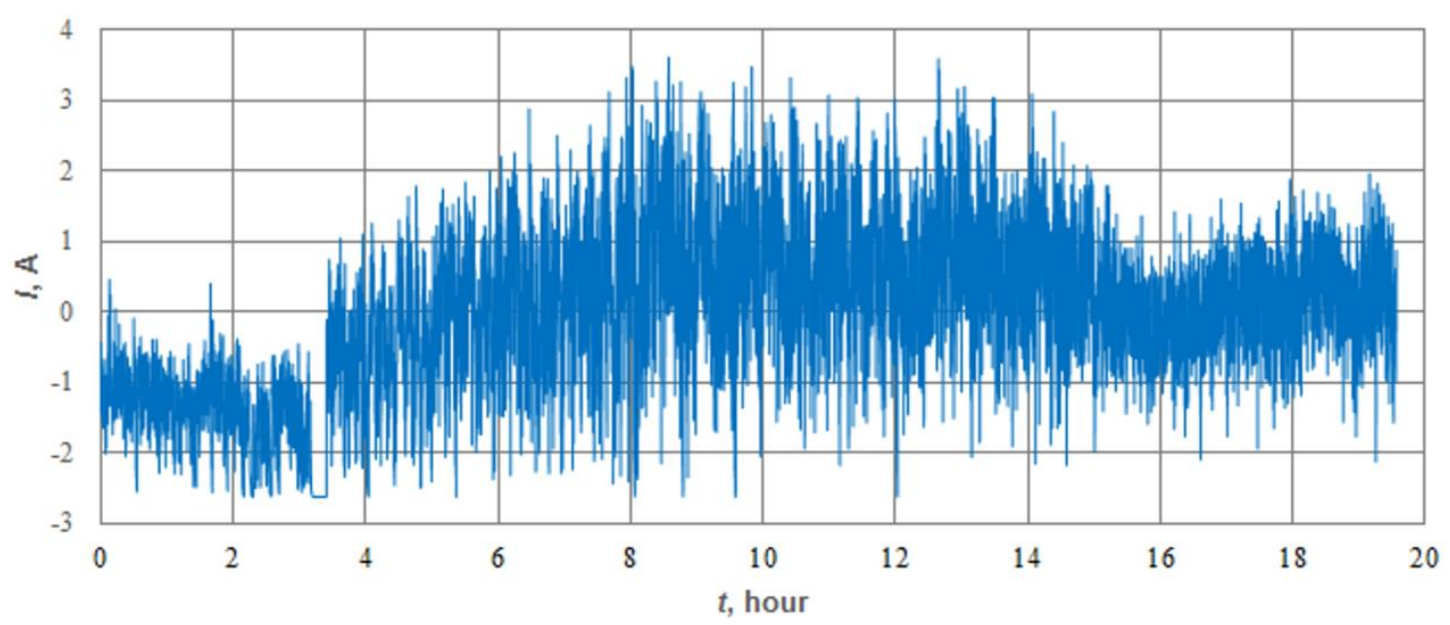

Fig. 1. Change in the charge/discharge current supplied to one battery cell according to the RES1 profile Puc. 1. График изменения зарядно-разрядного тока, подаваемого на одну ячейку батареи по профилю ВИЭ1

fig. 1. The time interval of 1 profile comprises $19.57 \mathrm{~h}$. The profile of RES2 was formed based on the same initial data; however, the discharge and charge modes were separated in time while maintaining the overall power balance.

To ensure comparable experimental conditions during RES profile tests, the following limitations were set. When the voltage reached 2.35 $V$ (full charge), the SB was transferred to the discharge section of the profile. When the voltage dropped to $1.8 \mathrm{~V}(\mathrm{DOD}=80 \%)$, the SB was transferred to the charge section of the profile.

\section{DETERMINATION OF STRESS FACTORS}

Since the ambient temperature was kept constant during the SB life tests, the temperature-related stress factors were not taken into account.

The charge factor (CF) is a dimensionless coefficient, its numerical values are determined through the ratio of the energy received and delivered by a SB, expressed in $A \cdot h$ per operation year:

$$
\begin{gathered}
C F=\frac{\mathrm{Ah}_{\text {charged }}}{\mathrm{Ah}_{\text {discharged }}}= \\
=-\frac{\int I_{\text {bat }} \cdot H\left(I_{\text {bat }}\right) \cdot d t}{\int I_{\text {bat }} \cdot H\left(-I_{\text {bat }}\right) \cdot d t},
\end{gathered}
$$

where $\mathrm{H}$ - the Heaviside function; $\mathrm{l}_{\mathrm{bat}}-\mathrm{SB}$ current, whose values are used to separate charge/discharge modes according to the given conditions: $I_{\text {bat }}>0$ - charge mode (charged), $I_{\text {bat }}$ $<0$ - discharge mode (discharged).

Depending on the microgrid design and the methods used for controlling the microgrid mode, the CF value can vary within a wide range. Thus, each specific current value will have a corresponding optimal CF value under a certain combination with other stress factors. The CF value can be used to assess the efficiency of the SB voltage regulation system, as well as possible deterioration mechanisms. Very low CF values lead to intensification of the sulfation and acid separation processes; moreover, an imbalance in the battery and cell charges in the SB bank is possible. Higher CF values promote corrosion and the loss of water and active mass [14].

The throughput factor $Q_{\text {thr }}$ is expressed through the normalized value of the SB annual discharge capacity:

$$
Q_{\mathrm{thr}}=-\frac{\int I_{\mathrm{bat}} \cdot H\left(-I_{\mathrm{bat}}\right) \cdot d t}{C_{N}},
$$

where $C_{N}$ - the rated SB capacitance, $A \cdot h$.

The effect of $Q_{\text {thr }}$ factor on the SB service life can only be considered in combination with two other PC and TL stress factors. In general, higher $Q_{\text {thr }}$ values contribute to the active mass 
deterioration of the SB plates, their crumbling and degradation.

The discharge rate factor is applied to assess the effect of high discharge currents on the SB lifetime. The function of discharge current distribution is used for calculating DR, where $1 \%$ of the capacity from the total SB throughput $\left(Q_{\text {thr }}\right)$ is discharged. These distribution parameters are determined by dividing the entire range of discharge currents into $M$ groups from the lowest $I_{1}$ to the highest $I_{M}$ current, with the subsequent determination of the corresponding frequency $f_{M}$ to construct a distribution histogram. By combining adjacent current groups in the total amount $L, m$ groups with the $I_{m}$ average current value, the $t_{m}$ time interval and the $f_{m}$ distribution frequency are extracted from the original histogram. These groups satisfy the following condition:

$$
\sum_{m=M-L}^{M} I_{\mathrm{m}} \cdot t_{\mathrm{m}}=0,01 \cdot Q_{\mathrm{thr}} \cdot C_{N}
$$

The DR value is determined by normalizing the average discharge current of all selected groups to the SB 10-hour rated discharge current $\mathrm{l}_{10}$ :

$$
D R=\frac{\sum_{m=M-L}^{M} I_{\mathrm{m}} \cdot f_{\mathrm{m}}}{I_{10}}
$$

A practical example of defining DR is discussed in [17]. Higher DR values increase the electrolyte temperature, losses and selfdischarge current of a SB.

Time between full charge. SB average time between full charge (in hours) is determined by the following equation:

$$
T F=\frac{\int H(90-S O C) d t}{n_{90 \%}}
$$

where $n_{90 \%}$ is the number of events per year that satisfy the condition: $\mathrm{SOC}(\mathrm{t})>90 \%$ and $\mathrm{SOC}$ (t $-\Delta t) \leq 90 \%$.

The choice of SOC $=90 \%$ as a criterion when calculating this factor is explained by the fact that determination of actual SOC values at high SB charge levels involve significant errors [14].

Higher TF values activate the process of forming insoluble sulfur compounds, which cannot be converted back into active substances. This ultimately leads to an irreversible decrease in the SB capacity relative to its rated value.

The time at low state of charge. The TL factor is the SB service time expressed as a percentage over the calculated period (usually per year) at a SOC value < 35\%:

$$
T L=\frac{\int H(35-S O C) d t}{\int d t} \cdot 100 .
$$

Long operation periods at low SOC levels accelerate sulfation and electrolyte decomposition. It should be noted that this stress factor has a significant negative impact on the service life of lead-acid SB, although its effect on other SB types is much smaller [14].

Partial cycling. The PC stress factor characterizes the weighted and averaged value of the battery discharge energy at different SOC levels to the total throughput, expressed as a percentage [17]:

$$
P C=(A+2 \cdot B+3 \cdot C+4 \cdot D+5 \cdot E) / 5,
$$

where the A - E coefficients represent the SB total discharge capacity in a specific SOC range, expressed as a percentage of the total annual discharge capacity.

The following SOC ranges are used to calculate the coefficient values in equation (7): $100-80 \%$ corresponds to coefficient $A, 85-70 \%$ - to coefficient B, $70-55 \%$ - to coefficient $C$, $55-40 \%$ - to coefficient $D$, and $40-0 \%$ - to coefficient $E$. The following equation demonstrates an example of calculating coefficient $A$ :

$$
A=\frac{\int I_{\text {bat }} \cdot H(S O C-85) \cdot H(100-S O C) \cdot H\left(-I_{\text {bat }}\right) \cdot d t}{\int I_{\text {bat }} \cdot H\left(-I_{\text {bat }}\right) \cdot d t} \cdot 100 .
$$


The other coefficients are determined in a similar manner. The effect of the PC factor on $\mathrm{SB}$ deterioration is manifested similarly to that of the TL stress factor.

\section{RESULTS AND DISCUSSION}

Fig. 2 shows a fragment of SB life tests registered for different load profiles. During the tests, the values of SB (I) charge/discharge current and cell voltage (V), as well as the calculated value of residual capacity (SOC) were recorded. The measurements were carried out with an interval of $1 \mathrm{~s}$ and were recorded in a spreadsheet for further processing.

Fig. 2 presents the experimental data for 2 charge/discharge cycles according to the DC profile, as well as 1 operating cycle for each RES profile. Following 5 consecutive cycles according to the given load profiles, the SB residual capacity was measured ${ }^{7}$. The obtained experimental dependences of the change in the SB residual capacity (SOC) on operating cycle numbers $\left(\mathrm{N}_{\text {cycle }}\right)$ and operating time $(\mathrm{t})$ are presented in fig. 3.
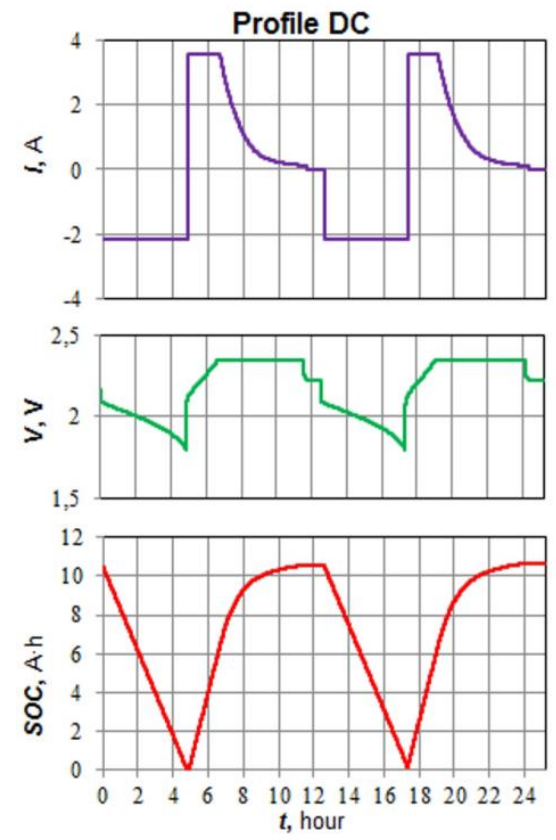
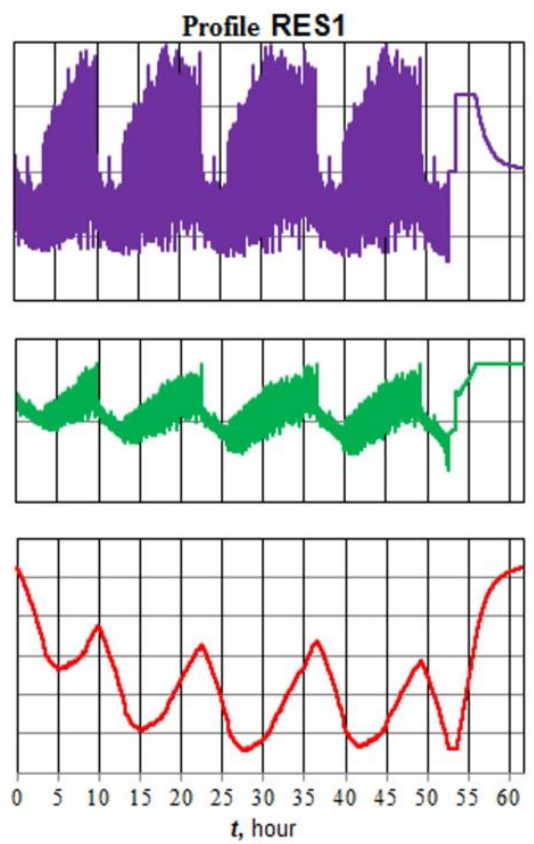
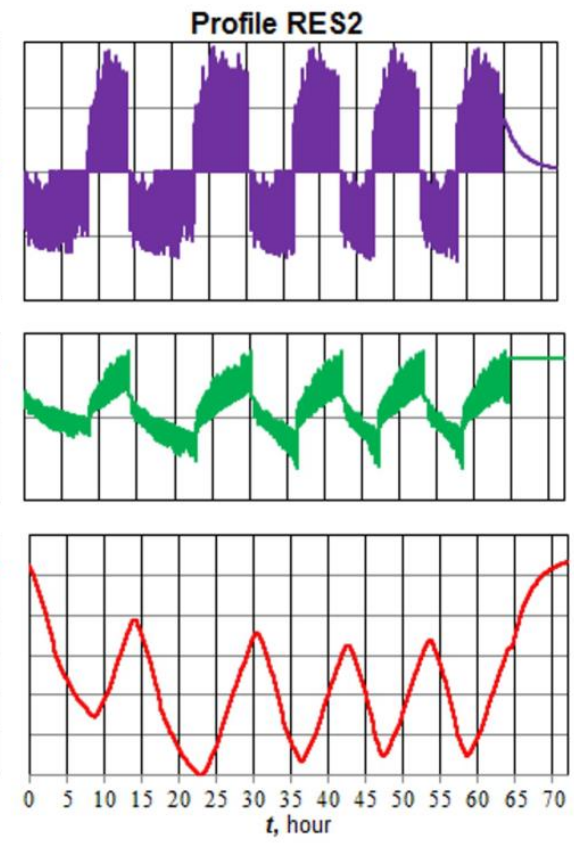

Fig. 2. Images obtained during storage battery life tests

Рuc. 2. Регистограммы ресурсных испытаний аккумуляторных батарей
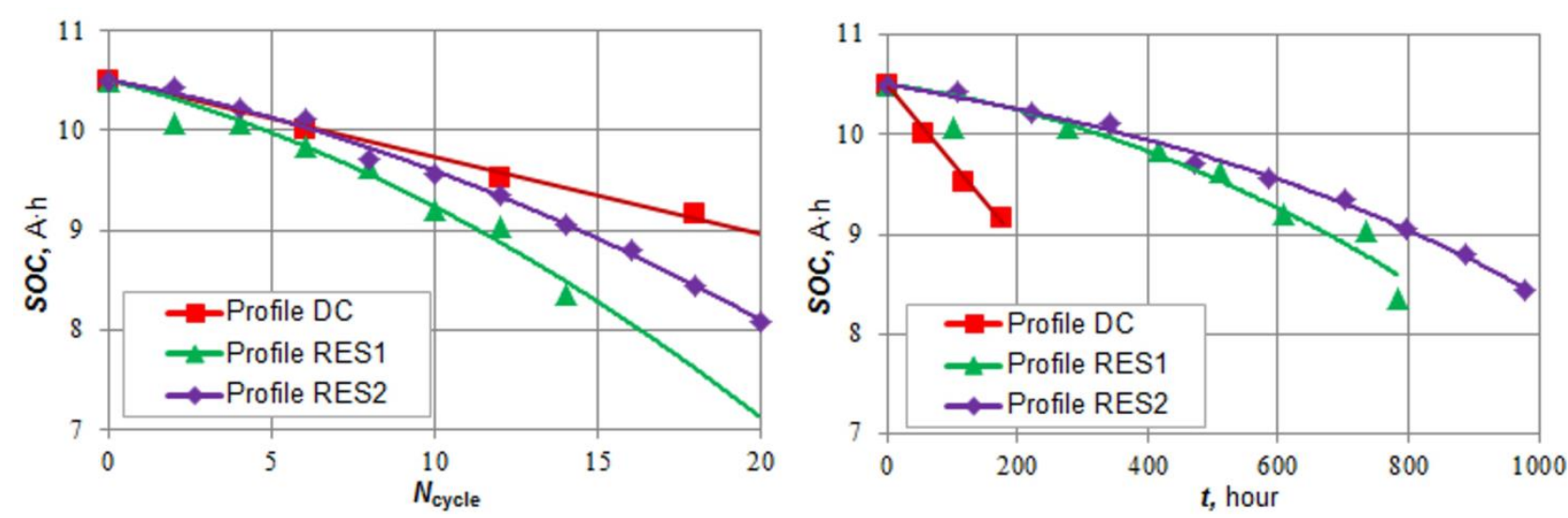

Fig. 3. Experimental dependences for the SB residual capacity on the number of operating cycles and operating time Puс. 3. Экспериментальные зависимости остаточной емкости аккумуляторных батарей от числа рабочих циклов и времени эксплуатации 
The experiments showed that the evaluation of the service life of SBs operated according to RES profiles based on the number of charge/discharge cycles and (or) the calendar operation from the data provided by the technical specification can lead to serious errors. This can be explained by significant differences in the full charge/discharge cycles between the DC and RES profiles, both in terms of duration and throughput. Performance models are more efficient [15, 16], allowing the residual battery life to be estimated by the amount of passed energy. Nevertheless, this method of determining the SB service life ignores the influence of other stress factors, thus leading to additional errors.

Our experiments revealed a significant effect of pulsed charge currents on SB degradation. When the battery is charged by pulsed currents, the voltage increases to the limiting values of 2.35-2.4 V per cell. Further charging will lead to a sharp growth in temperature and boiling off the electrolyte with irreversible consequences in terms of SB degradation [7]. In the experiments carried out on RES profiles, when the voltage increased to $2.35 \mathrm{~V}$, the tested cell was switched to the discharge mode, ensuring its protection from overcharging. Voltage control and charging current limitation allow the SB to be protected from overcharge modes; however, this leads to an incomplete battery charge and increases the operating time between full charge and at a low SOC level (see fig. 2). In addition, due to significant voltage ripples (for the RES1 profile, in particular), it is rather difficult to provide reliable and accurate control of the SOC value, which is essential for the effective operation of the microgrid energy storage mode control system.

The efficient recovery and accurate SOC control (see fig. 2) can be ensured by the standard two-tier DC charging mode based on the current-voltage method (DC profile). However, this requires the SB to be in a low-current charging mode (up to one percent of the rated capacity $\mathrm{C}_{\mathrm{N}}$ ) for a sufficiently long period of 5-7 h. The practical implementation of this $\mathrm{SB}$ charging mode in a RES-based microgrid is complicated by the excess electricity generated at such time intervals. The inability to consume this excess energy will lead to a drop in the RES ICUF and, accordingly, to deteriorated technical and economic characteristics of the entire energy system.

Tab. 2 presents the numerical values of the stress factors acting during SB operation for different load profiles. Fig. 4 shows the intensity of stress factors according by a gradation proposed in [14]: 1 - very low, 2 - low, 3 - medium, 4 - high, 5 - very high.

Table 2. SB operation stress factors for different load profiles

Таблица 2. Стресс-факторы эксплуатации аккумуляторных батарей для разных профилей нагрузки

\begin{tabular}{|c|c|c|c|}
\hline Stress factor & DC profile & RES1 profile & RES2 profile \\
\hline$C F$ & 1.0082 & 1.0018 & 1.0057 \\
\hline$Q_{\text {thr }}$ & 212 & 158 & 174 \\
\hline$D R$ & 2.08 & 1.04 & 0.99 \\
\hline$T F$ & 12.61 & 75.66 & 54.32 \\
\hline$T L$ & 21.15 & 59.25 & 39.09 \\
\hline$P C$ & 68.31 & 80.19 & 82.25 \\
\hline
\end{tabular}

A comparison of the SB operating conditions according to the DC and RES profiles reveals significant differences between all stress factors. It can be seen that the throughput factor has a decisive influence on the SB service life. An increase in $Q_{\text {thr }}$ values corresponds to a proportional acceleration of battery degradation; nevertheless, the battery life is determined by the cumulative impact of all stress factors. The obtained stress factors for the RES1 and RES2 profiles indicate a better retention of the SB service life when the charge/discharge modes are separated in time. The conducted tests demonstrated that the SB operating conditions according to these profiles are significantly different in terms of time between full charge (TF) and time at low state of charge (TL). These differences lead to a longer service life (by 10-14\%) of SB, when operated by the RES2 profile even at higher $Q_{\text {thr }}$ values.

The obtained results allowed us to develop recommendations for selecting an appropriate SB capacity and designing an efficient energy storage system for RES-based microgrids:

1. In RES-based microgrids, deep-discharge SBs demonstrating good cyclic characteristics should be applied. Among lead-acid batteries, 

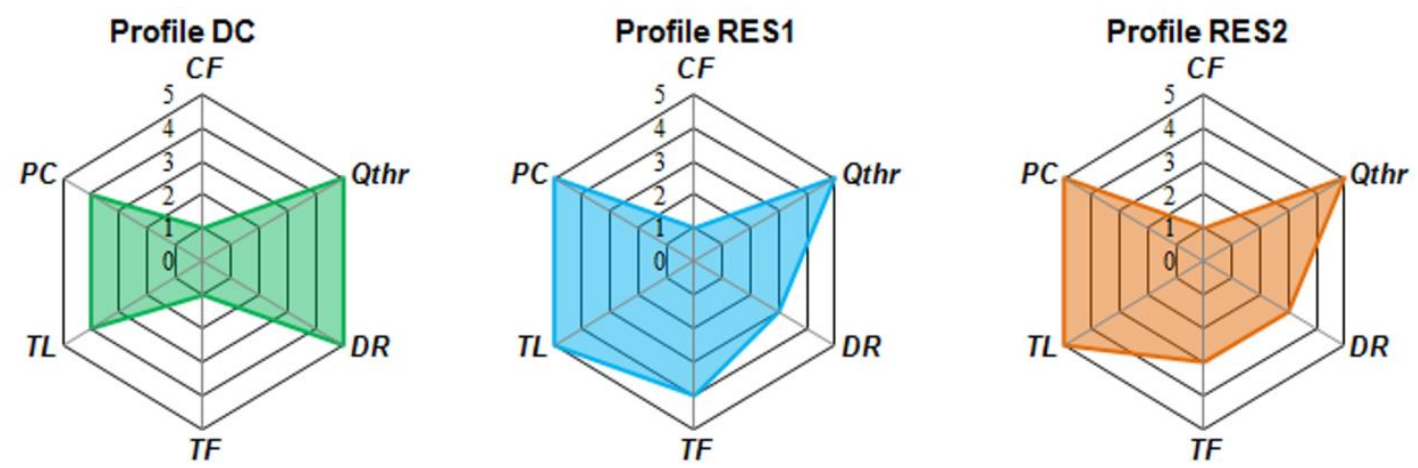

Fig. 4. Intensity of stress factors for different load profiles

Puc. 4. Сводные диаграммы интенсивности стресс-факторов для разных профилей нагрузки

gel batteries and those with armored electrodes $(\mathrm{OPzV}$ and $\mathrm{OPzS})$ meet these requirements to a large extent.

2. The nominal capacity of the energy storage device $\mathrm{Q}_{B B}(\mathrm{~W} \cdot \mathrm{h})$ should be selected according to the following conditions:

2.1. Covered energy consumption

$$
Q_{\mathrm{BB}} \geq \frac{E_{\mathrm{L}} \cdot T_{\mathrm{BB}}}{24 \cdot D O D \cdot \eta_{\mathrm{dch}}},
$$

where $E_{L}$ - the average daily energy consumed by the load; $\mathrm{T}_{\mathrm{BB}}$ - the required hours of power supply to consumers from the SB in the absence of electricity generated by a RES; $\eta_{d c h}$ - battery efficiency during the discharge phase, taking into account the converter efficiency.

2.2. Covered maximum power

$$
Q_{\mathrm{BB}} \geq 3 \cdot P_{\max },
$$

where $P_{\max }$ is the maximum electrical load.

3. The impact of high-amplitude pulse charge/discharge currents on the SB should be avoided, depending on the SB type. Thus, for lead-acid SBs, the charge/discharge currents should be limited to $I_{\text {bat }}=0.3 \cdot C_{N}$.

4. The SB operating modes with the residual capacity below the maximum allowable discharge level should be minimized or avoided. For lead-acid SBs, optimal DOD values range from $30 \%$ to $40 \%$.

5. SBs should be operated at a constant temperature using thermal containers equipped with a heating/air conditioning system.

6 . In cases where the energy storage circuit consists of series-parallel SB chains, balancing devices should be used.

These recommendations minimize the influence of stress factors on the performance of SBs, thus ensuring their maximum possible service life.

On the basis of the results obtained, a novel technical solution for developing an energy storage system for a RES-based microgrid was proposed [26]. Fig. 5 describes the proposed solution, which is based on a combined energy storage unit (CES) consisting of a supercapacitor module (SC) and 2 identical storage units based on SBs, alternately operating in the charge/discharge mode and a ballast load (BL). Here, the energy storage is connected to the microgrid busbars to control the energy balance in the system by regulating the $S B$ charge/discharge currents, supercapacitors and the ballast load. The application of 2 SB circuits makes it possible to implement the effective charging modes according to the "currentvoltage" method and a precise control of the residual capacity. The supercapacitor module mitigates power ripples over short periods of time, and, accordingly, optimizes the magnitude of charge/discharge currents. The proposed solution is expected to increase the SB reliability and service life, as well as the RES ICUF. In addition, the design of an autonomous inverter (Al) can be significantly simplified.

An experimental prototypes of CES with a rated power of $15 \mathrm{~kW}$ was manufactured at the VDM-Tekhnika LLC; its declared parameters were experimentally confirmed when operated as part of a wind photo-diesel microgrid $(\text { fig. } 6)^{10}$. The use of CES in a microgrid increases 


Энергетика
Power Engineering

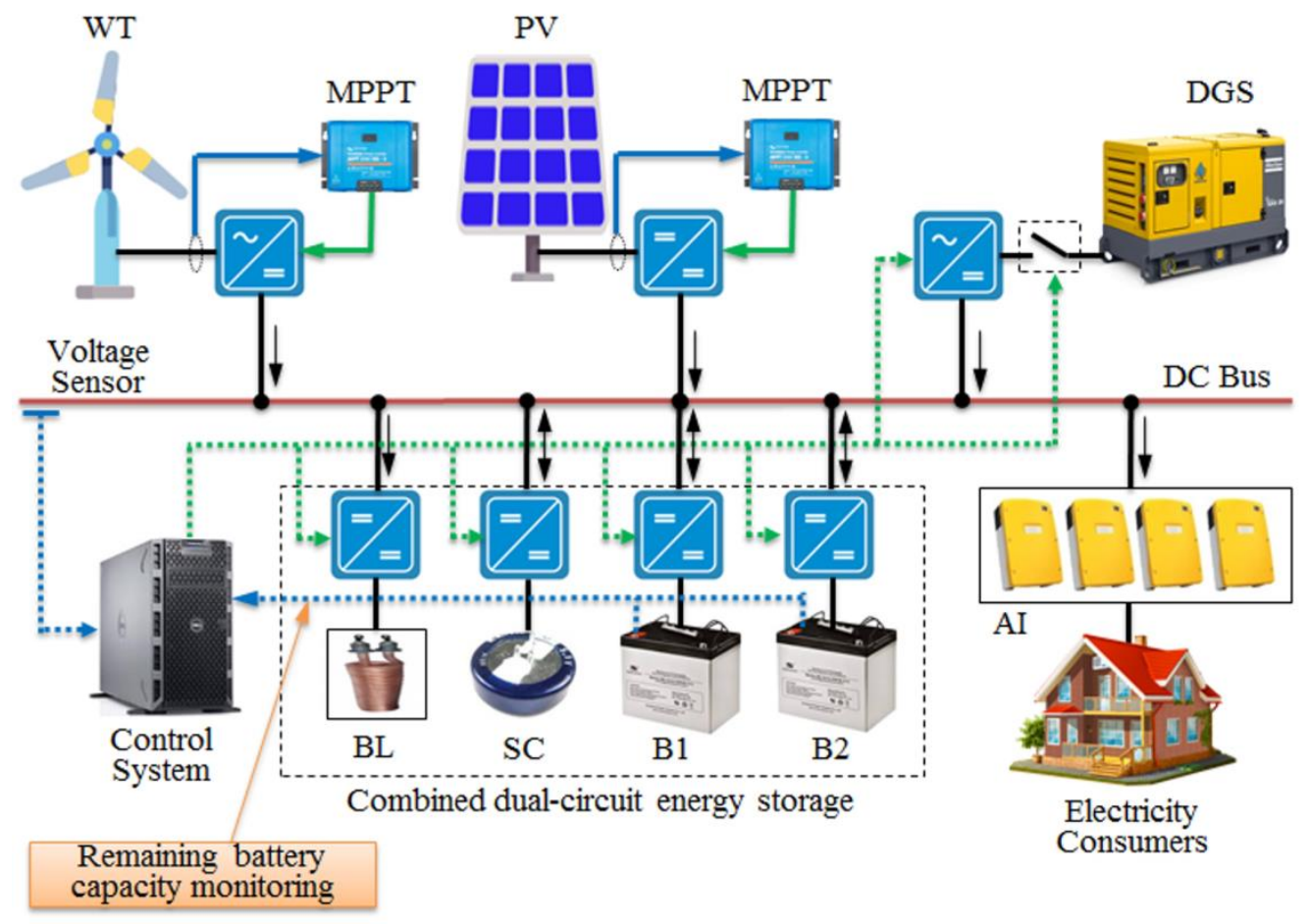

Fig. 5. The architecture proposed for hybrid energy systems based on renewable energy sources Рuc. 5. Предлагаемая архитектура построения гибридных энергетических систем на основе возобновляемых источников энергии
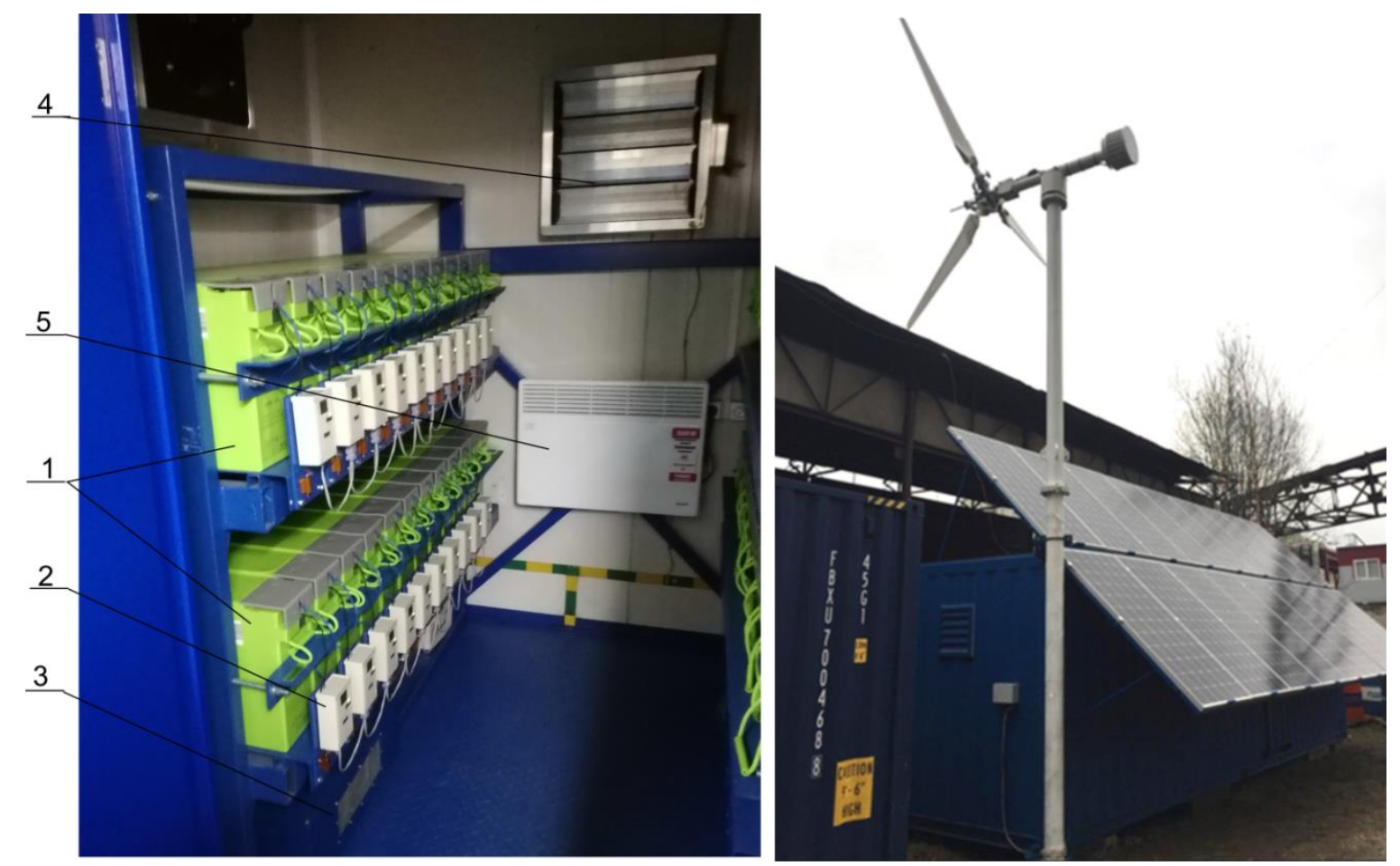

Fig. 6. An experimental model of a combined energy storage unit installed in a wind photo-diesel power complex: 1 - SB1 and SB2 modules; 2 - SB balancers; 3 - supercapacitor module; 4 - ventilation system; 5 - climate control system

Рис. 6. Экспериментальный образец комбинированного накопителя энергии в составе ветрофотодизельного энергетического комплекса: 1 - модули АБ1 и АБ2; 2 - балансиры АБ; 3 - суперконденсаторный модуль; 4- система вентиляции; 5 - система климат-контроля 
the SB service life by $20-30 \%$, ensures the static and dynamic stability of the local energy system with a response time to power changes of no more than $50 \mathrm{~ms}$, provides a fuel substitution level of at least $25 \%$ and reduces the electricity cost by $25-30 \%$.

\section{CONCLUSIONS}

The conducted experimental studies allowed us to determine the numerical values of stress factors, which reflect the relationship between the operating conditions and service life of SBs used in microgrids. On the basis of a comparative analysis of the effect of various stress factors on the SB service life, recommendations were formulated for selecting an optimal battery capacity, as well as for developing an efficient energy storage system for RES-based microgrids.

A novel technical solution for the design of an energy storage system was proposed, implemented and experimentally tested. This solution provides for an increase in the energy efficiency of RES-based microgrids.

\section{References}

1. Salas V, Suponthana W, Salas RA. Overview of the offgrid photovoltaic diesel batteries systems with $\mathrm{AC}$ loads. Applied Energy. 2015;157:195-216.

https://doi.org/10.1016/j.apenergy.2015.07.073

2. Akinyele D, Belikov J, Levron Yo. Battery storage technologies for electrical applications: impact in stand-alone photovoltaic systems. Energies. 2017;10(11):1760. https://doi.org/10.3390/en10111760

3. May GJ, Davidson A, Monahov B. Lead batteries for utility energy storage: a review. Journal of Energy Storage. 2018;15:145-157.

https://doi.org/10.1016/j.est.2017.11.008

4. Jakhrani $A Q$, Rigit $A R H$, Othman A-K, Samo SR, Kamboh SA. Life cycle cost analysis of a standalone PV system. In: IEEE International Conference on Green and Ubiquitous Technology. 7-8 July 2012, Bandung. Bandung: IEEE; 2012, p. 82-85.

https://doi.org/10.1109/GUT.2012.6344195

5. Ataei A, Nedaei M, Rashidi R, Yoo Changkyoo. Optimum design of an off-grid hybrid renewable energy system for an office building. Journal of Renewable and Sustainable Energy. 2015;7:053123. https://doi.org/10.1063/1.4934659

6. Obukhov SG, Plotnikov IA, Ibrahim A, Masolov VG. Dual energy storage for hybrid energy systems with renewable energy sources. Izvestiya Tomskogo politekhnicheskogo universiteta. Inzhiniring georesursov $=$ Bulletin of the Tomsk Polytechnic University. Geo Assets Engineering. 2020;331(1):64-76. https://doi.org/10.18799/24131830/2020/1/2448 (In Russ.) 7. Hu Xiaosong, Martinez CM, Yang Yalian. Charging, power management, and battery degradation mitigation in plug-in hybrid electric vehicles: a unified cost-optimal approach. Mechanical Systems and Signal Processing. 2017;87(B):4-16.

https://doi.org/10.1016/j.ymssp.2016.03.004

8. Bordin C, Anuta HO, Crossland A, Gutierrez IL, Dent CJ, Vigo D. A linear programming approach for battery degradation analysis and optimization in offgrid power systems with solar energy integration. Renewable Energy. 2017;101:417-430.

https://doi.org/10.1016/j.renene.2016.08.066
9. Ruddell AJ, Dutton AG, Wenzl H, Ropeter C, Sauer DU, Merten J, et al. Analysis of battery current microcycles in autonomous renewable energy systems. Journal of Power Sources. 2002;112(2):531-546.

https://doi.org/10.1016/S0378-7753(02)00457-3

10. Brik K, Ammar F. Causal tree analysis of depth degradation of the lead acid battery. Journal of Power Sources. 2013;228:39-46.

https://doi.org/10.1016/j.jpowsour.2012.10.088

11. Sauer DU, Garche J. Optimum battery design for applications in photovoltaic systems - theoretical considerations. Journal of Power Sources. 2001;95(1-2):130-134. https://doi.org/10.1016/S0378-7753(00)00642-X

12. Wenzl Heinz, Baring-Gould Ian, Kaiser R, Liaw Bor Yann, Lundsager $P$, Manwell J, et al. Life prediction of batteries for selecting the technically most suitable and cost effective battery. Journal of Power Sources. 2005;144(2):373-384.

https://doi.org/10.1016/j.jpowsour.2004.11.045

13. Bindner $H$, Cronin $T$, Lundsager $P$, Manwell JF, $A b$ dulwahid U, Baring-Gould I. Lifetime Modelling of Lead Acid Batteries. Available from:

https://backend.orbit.dtu.dk/ws/portalfiles/portal/7710966/ri S_r_1515.pdf [Accessed 17th February 2021].

14. Svoboda V, Wenzl H, Kaiser R, Jossen A, BaringGould I, Manwell J, et al. Operating conditions of batteries in off-grid renewable energy systems. Solar Energy. 2007;81(11):1409-1425.

https://scholarworks.umass.edu/mie_faculty_pubs/511

15. Lee M, Park J, Na SI, Choi HS, Bu BS, Kim J. An analysis of battery degradation in the integrated energy storage system with solar photovoltaic generation. Electronics. 2020;9(4):701.

https://doi.org/10.3390/electronics9040701

16. Hlal MI, Ramachandaramurthy VK, Sarhan A, Pouryekta A, Subramaniam U. Optimum battery depth of discharge for off-grid solar PV/battery system. Journal of Energy Storage. 2019;26:100999.

https://doi.org/10.1016/j.est.2019.100999

17. Lujano-Rojas JM, Dufo-López R, Atencio-Guerra JL, Rodrigues EMG, Bernal-Agustín JL, Catalão JPS. Operating conditions of lead-acid batteries in the optimization of 
hybrid energy systems and microgrids. Applied Energy. 2016;179:590-600.

https://doi.org/10.1016/j.apenergy.2016.07.018

18. Narayan N, Papakosta T, Vega-Garita V, Qin Zian, Popovic-Gerber J, Bauer P, Zeman M. Estimating battery lifetimes in Solar Home System design using a practical modelling methodology. Applied Energy. 2018;228:16291639. https://doi.org/10.1016/j.apenergy.2018.06.152

19. Layadi TM, Champenois G, Mostefai M, Abbes D. Lifetime estimation tool of lead-acid batteries for hybrid power sources design. Simulation Modelling Practice and Theory. 2015;54:36-48.

https://doi.org/10.1016/j.simpat.2015.03.001

20. Alsaidan I, Khodaei A, Gao W. A Comprehensive battery energy storage optimal sizing model for microgrid applications. In: IEEE Transactions on Power Systems. 2018;33(4):3968-3980.

https://doi.org/10.1109/TPWRS.2017.2769639

21. Schiffer J, Sauer DU, Bindner H, Cronin T, Lundsager $P$, Kaiser R. Model prediction for ranking lead-acid batteries according to expected lifetime in renewable energy systems and autonomous power-supply systems. Journal of Power Sources. 2007;168(1):66-78. https://doi.org/10.1016/j.jpowsour.2006.11.092 22. Dufo-López R, Lujano-Rojas JM, Bernal-Agustín JL. Comparison of different Lead-acid battery lifetime prediction models for use in simulation of stand-alone photovoltaic systems. Applied Energy. 2014;115:242-253. https://doi.org/10.1016/j.apenergy.2013.11.021

23. Dufo-López R, Cortés-Arcos T, Artal-Sevil JS, Bernal-Agustín JL. Comparison of Lead-acid and Li-ion batteries lifetime prediction models in stand-alone photovoltaic systems. Applied Sciences. 2021;11(3):1099. https://doi.org/10.3390/app11031099

24. Moncecchi M, Brivio C, Mandelli S, Merlo M. Battery Energy Storage Systems in Microgrids: Modeling and Design Criteria. Energies. 2020;13(8):2006. https://doi.org/10.3390/en13082006

25. García-Vera YiE, Dufo-López R, Bernal-Agustín JL. Optimization of isolated hybrid microgrids with renewable energy based on different battery models and technologies. Energies. 2020;13(3):581.

https://doi.org/10.3390/en13030581

26. Masolov VG, Masolov NV, Muravlev AI, Obukhov SG. Standalone power supply system with a combined energy storage device. Patent RF, no. 2726735; 2019. (In Russ.)

\section{Список литературы}

1. Salas V., Suponthana W., Salas R.A. Overview of the off-grid photovoltaic diesel batteries systems with $A C$ loads // Applied Energy. 2015. Vol. 157. P. 195-216. https://doi.org/10.1016/j.apenergy.2015.07.073

2. Akinyele D., Belikov J., Levron Yo. Battery storage technologies for electrical applications: impact in standalone photovoltaic systems // Energies. 2017. Vol. 10. Iss. 11. P. 1760. https://doi.org/10.3390/en10111760

3. May G.J., Davidson A., Monahov B. Lead batteries for utility energy storage: a review // Journal of Energy Storage. 2018. Vol. 15. P. 145-157.

https://doi.org/10.1016/j.est.2017.11.008

4. Jakhrani A.Q., Rigit A.R.H., Othman A.-K., Samo S.R., Kamboh S.A. Life cycle cost analysis of a standalone PV system // IEEE International Conference on Green and Ubiquitous Technology (Bandung, 7-8 July 2012). Bandung: IEEE, 2012. P. 82-85.

https://doi.org/10.1109/GUT.2012.6344195

5. Ataei A., Nedaei M., Rashidi R., Yoo Changkyoo. Optimum design of an off-grid hybrid renewable energy system for an office building // Journal of Renewable and Sustainable Energy. 2015. Vol. 7. P. 053123.

https://doi.org/10.1063/1.4934659

6. Обухов С.Г., Плотников И.А., Ибрагим А., Масолов В.Г. Двухконтурный накопитель энергии для гибридных энергетических систем с возобновляемыми источниками энергии // Известия Томского политехнического университета. Инжиниринг георесурсов. 2020. T. 331. No. 1. C. 64-76.

https://doi.org/10.18799/24131830/2020/1/2448

7. Hu Xiaosong, Martinez C.M., Yang Yalian. Charging, power management, and battery degradation mitigation in plug-in hybrid electric vehicles: a unified cost-optimal approach // Mechanical Systems and Signal Processing.
2017. Vol. 87. Part B. P. 4-16.

https://doi.org/10.1016/j.ymssp.2016.03.004

8. Bordin C., Anuta H.O., Crossland A., Gutierrez I.L., Dent C.J., Vigo D. A linear programming approach for battery degradation analysis and optimization in off-grid power systems with solar energy integration // Renewable Energy. 2017. Vol. 101. P. 417-430.

https://doi.org/10.1016/j.renene.2016.08.066

9. Ruddell A.J., Dutton A.G., Wenzl H., Ropeter C., Sauer D.U., Merten J., Orfanogiannis C., et al. Analysis of battery current microcycles in autonomous renewable energy systems // Journal of Power Sources. 2002. Vol. 112. Iss. 2. P. 531-546. https://doi.org/10.1016/S03787753(02)00457-3

10. Brik K., Ammar F. Causal tree analysis of depth degradation of the lead acid battery // Journal of Power Sources. 2013. Vol. 228. P. 39-46.

https://doi.org/10.1016/j.jpowsour.2012.10.088

11. Sauer D.U., Garche J. Optimum battery design for applications in photovoltaic systems - theoretical considerations // Journal of Power Sources. 2001. Vol. 95. Iss. 1-2. P. 130-134. https://doi.org/10.1016/S03787753(00)00642-X

12. Wenzl Heinz, Baring-Gould lan, Kaiser R., Liaw Bor Yann, Lundsager P., Manwell J., et al. Life prediction of batteries for selecting the technically most suitable and cost effective battery // Journal of Power Sources. 2005. Vol. 144. Iss. 2. P. 373-384.

https://doi.org/10.1016/j.jpowsour.2004.11.045

13. Bindner H., Cronin T., LundsagerP., Manwell J.F., Abdulwahid U., Baring-Gould I. Lifetime modelling of lead acid batteries. [Электронный pecypc]. URL: https://backend.orbit.dtu.dk/ws/portalfiles/portal/7710966/ri S_r_1515.pdf (17.02.2021). 
14. Svoboda V., Wenzl H., Kaiser R., Jossen A., BaringGould I., Manwell J., et al. Operating conditions of batteries in off-grid renewable energy systems // Solar Energy. 2007. Vol. 81. Iss. 11. P. 1409-1425.

https://scholarworks.umass.edu/mie_faculty_pubs/511 15. Lee M., Park J., Na S.I., Choi H.S., Bu B.S., Kim J. An analysis of battery degradation in the integrated energy storage system with solar photovoltaic generation /I Electronics. 2020. Vol. 9. Iss. 4. P. 701.

https://doi.org/10.3390/electronics 9040701

16. Hlal M.I., Ramachandaramurthy V.K., Sarhan A., Pouryekta A., Subramaniam U. Optimum battery depth of discharge for off-grid solar PV/battery system // Journal of Energy Storage. 2019. Vol. 26. P. 100999. https://doi.org/10.1016/j.est.2019.100999

17. Lujano-Rojas J.M., Dufo-López R., Atencio-Guerra J.L., Rodrigues E.M.G., Bernal-Agustín J.L., Catalão J.P.S. Operating conditions of lead-acid batteries in the optimization of hybrid energy systems and microgrids /I Applied Energy. 2016. Vol. 179. P. 590-600.

https://doi.org/10.1016/j.apenergy.2016.07.018

18. Narayan N., Papakosta T., Vega-Garita V., Qin Zian, Popovic-Gerber J., Bauer P., Zeman M. Estimating battery lifetimes in Solar Home System design using a practical modelling methodology // Applied Energy. 2018. Vol. 228. P. 1629-1639.

https://doi.org/10.1016/j.apenergy.2018.06.152

19. Layadi T.M., Champenois G., Mostefai M., Abbes D. Lifetime estimation tool of lead-acid batteries for hybrid power sources design // Simulation Modelling Practice and Theory. 2015. Vol. 54. P. 36-48.

https://doi.org/10.1016/j.simpat.2015.03.001

20. Alsaidan I., Khodaei A., Gao W. A Comprehensive battery energy storage optimal sizing model for microgrid

\section{INFORMATION ABOUT THE AUTHORS}

\section{Sergey G. Obukhov,}

Dr. Sci. (Eng.), Associate Professor,

Professor of the Department of Electric Power

and Electrical Engineering,

National Research Tomsk Polytechnic University;

30 Lenin Ave., Tomsk 634050, Russia;

$\bowtie$ e-mail: serob99@mail.ru

\section{Igor A. Plotnikov,}

Cand. Sci. (Eng.), Associate Professor,

Associate Professor of the Department of Electric Power and Electrical Engineering, National Research Tomsk Polytechnic University;

30 Lenin Ave., Tomsk 634050, Russia;

e-mail: igorplt@tpu.ru applications // IEEE Transactions on Power Systems. 2018. Vol. 33. Iss. 4. P. 3968-3980.

https://doi.org/10.1109/TPWRS.2017.2769639

21. Schiffer J., Sauer D.U., Bindner H., Cronin T., Lundsager P., Kaiser R. Model prediction for ranking leadacid batteries according to expected lifetime in renewable energy systems and autonomous power-supply systems // Journal of Power Sources. 2007. Vol. 168. Iss. 1. P. 6678. https://doi.org/10.1016/i.jpowsour.2006.11.092

22. Dufo-López R., Lujano-Rojas J.M., Bernal-Agustín J.L. Comparison of different Lead-acid battery lifetime prediction models for use in simulation of stand-alone photovoltaic systems // Applied Energy. 2014. Vol. 115. P. 242-253. https://doi.org/10.1016/j.apenergy.2013.11.021

23. Dufo-López R., Cortés-Arcos T., Artal-Sevil J.S., Bernal-Agustín J.L. Comparison of Lead-acid and Li-ion batteries lifetime prediction models in stand-alone photovoltaic systems // Applied Sciences. 2021. Vol. 11. Iss. 3. P. 1099. https://doi.org/10.3390/app11031099

24. Moncecchi M., Brivio C., Mandelli S., Merlo M. Battery energy storage systems in microgrids: modeling and design criteria // Energies. 2020. Vol. 13. Iss. 8. P. 2006. https://doi.org/10.3390/en13082006

25. García-Vera Yi.E., Dufo-López R., Bernal-Agustín J.L. Optimization of isolated hybrid microgrids with renewable energy based on different battery models and technologies // Energies. 2020. Vol. 13. Iss. 3. P. 581. https://doi.org/10.3390/en13030581

26. Пат. 2726735 C1, Российская Федерация, Н02J 7/34 (2006.01). Система автономного электроснабжения С комбинированным накопителем энергии / В.Г. Масолов, Н.В. Масолов, А.И. Муравлев, С.Г. Обухов; заявитель и патентообладатель ООО «ВДМ-техника». Заявл. 23.08.2019; опубл. 15.07.2020. Бюл. № 20.

\section{ИНФОРМАЦИЯ ОБ АВТОРАХ}

\section{Обухов Сергей Геннадьевич,}

доктор технических наук, доцент, профрессор Отделения электроэнергетики и электротехники, Национальный исследовательский Томский политехнический университет, 634050 , г. Томск, пр. Ленина, 30, Россия; $\square$ e-mail: serob99@mail.ru

\section{Плотников Игорь Александрович,}

кандидат технических наук, доцент, доцент Отделения электроэнергетики и электротехники,

Национальный исследовательский Томский политехнический университет

634050, г. Томск, пр. Ленина, 30, Россия; e-mail: igorplt@tpu.ru 
Vladimir G. Masolov,

Cand. Sci. (Eng.),

Director General of VDM-Tekhnika LLC,

27/3/206, Pavlovskaya St., Moscow 115093, Russia;

e-mail:vdm-tech@mail.ru

\section{Contribution of the authors}

The authors contributed equally to this article.

\section{Conflict of interests}

The authors declare no conflict of interests.

The final manuscript has been read and approved by all the co-authors.

\section{Information about the article}

The article was submitted 15.06.2021; approved after reviewing 13.07.2021; accepted for publication 18.08.2021.

\author{
Масолов Владимир Геннадьевич, \\ кандидат технических наук, \\ генеральный директор ООО «ВДМ-техника»; \\ 115093, г. Москва, ул. Павловская, 27/3/206, Россия; \\ e-mail:vdm-tech@mail.ru
}

\section{Заявленный вклад авторов}

Bce авторы сделали эквивалентный вклад в подготовку публикации.

\section{Конфрликт интересов}

Авторы заявляют об отсутствии конфлликта интересов.

Все авторы прочитали и одобрили окончательный вариант рукописи.

\section{Информация о статье}

Статья поступила в редакцию 15.06.2021; одобрена после рецензирования 13.07.2021; принята к публикации 18.08.2021. 